\title{
A Correlational Study on the Effect of National Crisis on the Mental Health of Students at the Faculty of Nursing, Tripoli Libya and their Academic Performance
}

\author{
Maria Cristina Arboleda-Tinay, RN, MAN ${ }^{1}$, Evelyn Macasieb, RN, MSN², Joyce Juanita De Vera, RN, MAN , \\ Jane Fabian, RN, MAN ${ }^{4}$ \\ ${ }^{1,2,3,4}$ Faculty of Nursing, University of Tripoli, Tripoli, Libya
}

\begin{abstract}
The study aimed to determine the relationship of the effects of the national crisis on the mental of the students and their academic performance. Specifically, this study aimed to answer the following questions: 1.)What are the effects of the National crisis on the Mental Health of the students per semester level? 2.)What are the academic performance of the students per semester level? 3.)Is there a significant relationship between the effect of the national crisis on the mental health status of the students at the Faculty of Nursing and their academic performance? The findings that the researcher was able to extract from the study were: 1) The effects of the National crisis on the mental health of the students disclosed the same verbal interpretation of "A good bit of the time" for all semester levels. It is surprising to note that the summary from all semester levels is the same. Indeed it can be said that the mental health of the students although not greatly affected, there's still some effects that could be seen and that it doesn't matter which semesters they are currently in. 2) The academic performance of the students disclosed that semester 8 have a verbal interpretation of "Very Good", semesters 3, 5,6 and 7 as "Good" and semesters 1,2 and 4 as "Fair". The academic performance of the students are not the same for semester 1-8. It is more difficult for the lower years like semester 1, 2 and 4 to adapt as they revealed an overall interpretation of "Fair". And only students at the last semester was able to get the verbal interpretation of "Very Good". It is worthwhile to note that as the student progresses, the more likely for them to cope with their academic performance. 3) Statistical evidence shows that an $r=0.26$ shows a positive weak relationship among variables. Though it's not that high, indeed, the mental health of the students can be a predictor to their academic performance.
\end{abstract}

KEY WORDS: Academic Performance, Mental Health, National Crisis

\section{INTRODUCTION}

Among the consequence of war, the negative impact it had on the mental health of the people of the society in general has been catastrophic. War destroys communities and families and lives. It leads to widespread human suffering and population displacement, it often disrupts the development of the social and economic fabric of nations. It disturbs and interrupts people's ability to live in peace and harmony. It corrupts nations and ruins generations and effects the youth especially on a large scale studies have shown that conflict situations cause more mortality and disability.

The effects of war include long-term physical and psychological harm to children and adults, as well as reduction in material and human capital. Death as a result of wars is simply the "tip of the iceberg". Other consequences, besides death, are not well documented. They include endemic poverty, malnutrition, disability, economic/social decline and psycho-social illness, to mention only a few.

It becomes very difficult for children to grow up normally in an environment filled with fear and death and hopelessness and still manage to find a way to live their lives to its full potential. When the different governments and cities of Libya fight each other to death for power and money and status, the balance of peace and well - being will be disrupted and although the situation in Libya has been extremely difficult to live with and to handle, the youth of our society are still fighting through it all to have a good chance at education and to achieve their goal of being a part of the next generation that would build a better future for our country. 


\section{International Journal of Current Science Research and Review}

ISSN: 2581-8341

Volume 04 Issue 08 August 2021

DOI: 10.47191/ijesrr/V4-i8-12, Impact Factor: 5.825

IJCSRR@ 2021

Www.ijcsrr.org

The impact of Libya's nine-year war on civilians is "incalculable", a UN official has said, with rising casualties and nearly 900,000 people now needing assistance.

The impact of wars on the mental health of the civilian population is one of the most significant studies of the general population show a definite increase in the incidence and prevalence of mental disorders. Women are more affected than men. Other vulnerable groups are children, the elderly and the disabled. Prevalence rates are associated with the degree of trauma, and the availability of physical and emotional support. The use of cultural and religious coping strategies is frequent in developing countries. ${ }^{1}$

The impact of wars on the mental health of the civilian population is one of the most significant studies of the general population show a definite increase in the incidence and prevalence of mental disorders. Women are more affected than men. Other vulnerable groups are children, the elderly and the disabled. Prevalence rates are associated with the degree of trauma, and the availability of physical and emotional support. The use of cultural and religious coping strategies is frequent in developing countries.

At this juncture, the researchers are bent on pursuing this study entitled, "A Correlational Study on the Effect of National Crisis on the Mental Health of the Students of the Faculty of Nursing, University of Tripoli and their Academic Performance".

\section{METHODS}

This study employed the Descriptive Correlational method of research. The respondents of this study were the students of University of Tripoli from the Faculty of Nursing, which is composed of 490 students. Out of the 490 total population two hundred forty seven (247) samples formed the respondents. Thirty three (33) from Semester 1, Thirty three (33) from Semester 2, Thirty (30) from Semester 3, Thirty one (31) Semester 4, Thirty (30) Semester 5, Thirty (30) Semester 6, Thirty (30) Semester 7 and Thirty (30) from Semester 8. The researchers made use of Triangulation in research where we employed a combination of two (2) Sampling Techniques. The convenience or accidental sampling and purposive sampling to ensure validity of data for the academic performance. Those students present during the actual data collection were the one who formed the respondents of the study.

The researcher made use both of primary data and secondary data as well as a tool in collecting data. The questionnaire with the use of Likert scale measures the effect of the national crisis on the mental health of the students. The researchers also made use of the secondary data to measure the academic performance of the respondents. The general weighted average of the students for each semester level was taken into account to measure the second variable of the study.

Communication was sent to the Dean of the University of Tripoli, Faculty of Nursing, for the approval of the conduct of data collection. After the permission was sought, the researchers proceed on the actual conduct of data collection by distributing questionnaires to the respondents and retrieving it on the same day of the Registration schedule of the students. For the secondary data, a communication was sent to the Dean and the Office of the Studies \& Examination to seek perusal on the retrieval of grades. After that the permission was sought, the Studies \& Examination Office provided the data on the academic performance of students. After the data was retrieved, it was treated statistically.

\section{RESULTS}

Detailed scrutiny of Table 1 reveals an overall mean of 2.59 which have a verbal interpretation of "A good bit of the time".

Table 1. Mean and Verbal Interpretation of the effects of the National Crisis on the Mental Health of the Students on Semester 1

\begin{tabular}{|l|l|l|}
\hline Indicator & Mean & Verbal Interpretation \\
\hline 1. Has your daily life been full of things that were interesting to you? & 3.59 & Most of the Time \\
\hline 2. Did you feel depressed & 2.44 & Some of the Time \\
\hline 3. Have you felt loved and wanted & 3.53 & Most of the Time \\
\hline 4. Have you been a very nervous person? & 2.98 & A good bit of the Time \\
\hline 5. Have you been in firm control of your behavior thoughts,emotions, and feelings? & 3.01 & A good bit of the Time \\
\hline
\end{tabular}




\section{International Journal of Current Science Research and Review}

ISSN: 2581-8341

Volume 04 Issue 08 August 2021

DOI: 10.47191/ijesrr/V4-i8-12, Impact Factor: 5.825

IJCSRR@ 2021

Www.ijcsrr.org

\begin{tabular}{|c|c|c|c|c|}
\hline \multicolumn{3}{|c|}{ 6. Have you felt tense or high-strung? } & 2.89 & A good bit of the Time \\
\hline \multicolumn{3}{|c|}{ 7. Have you felt calm and peaceful? } & 2.31 & Some of the time \\
\hline \multicolumn{3}{|c|}{ 8. Have you felt emotionally stable? } & 2.04 & Some of the time \\
\hline \multicolumn{3}{|c|}{ 9. Have you felt downhearted and blue? } & 2.52 & A good bit of the Time \\
\hline \multicolumn{3}{|c|}{ 10. Were you able to relax without difficult? } & 2.19 & Some of the time \\
\hline \multicolumn{3}{|c|}{ 11. Have you felt restless, fidgety, or impatient? } & 2.77 & A good bit of the time \\
\hline \multicolumn{3}{|c|}{ 12. Have you been moody, or brooded about things? } & 2.65 & A good bit of time \\
\hline \multicolumn{3}{|c|}{ 13. Have you felt cheerful, lighted-hearted? } & 2.43 & Some of the time \\
\hline \multicolumn{3}{|c|}{ 14. Have you been in low, or very low spirits? } & 2.13 & Some of the time \\
\hline \multicolumn{3}{|c|}{ 15. Were you happy person? } & 3.25 & A good bit of time \\
\hline \multicolumn{3}{|c|}{ 16. Did you feel you had nothing to look forward? } & 1.89 & Some of the time \\
\hline \multicolumn{3}{|c|}{ 17. Have you felt so down in the dumps that nothing could cheer you up? } & 1.86 & Some of the time \\
\hline \multicolumn{3}{|c|}{ 18. Have you been anxious or worried? } & 2.22 & Some of the time \\
\hline \multicolumn{3}{|l|}{ Overall } & 2.59 & A good bit of time \\
\hline Legend & $\begin{array}{r}4.51-5.00 \\
3.51-4.50 \\
2.51-3.50 \\
1.51-2.50 \\
0.51-1.50 \\
0-0.50\end{array}$ & $\begin{array}{l}\text { All of the time } \\
\text { Most of the time } \\
\text { A good bit of the time } \\
\text { Some of the time } \\
\text { A little bit of the time } \\
\text { None of the time }\end{array}$ & & \\
\hline
\end{tabular}

Cursory inspection of Table 2 reflecting the results of the overall mean of 2.79 disclosed that most of the indicator shows a verbal interpretation of "A good bit of the time".

Table 2. Mean and Verbal Interpretation of the effects of the National Crisis on the Mental Health of the Students on Semester 2

\begin{tabular}{|l|l|l|}
\hline Indicator & Mean & Verbal Interpretation \\
\hline 1. Has your daily life been full of things that were interesting to you? & 3.39 & A good bit of the Time \\
\hline 2. Did you feel depressed & 3.24 & A good bit of the Time \\
\hline 3. Have you felt loved and wanted & 3.51 & Most of the Time \\
\hline 4. Have you been a very nervous person? & 2.87 & A good bit of the Time \\
\hline $\begin{array}{l}\text { 5. Have you been in firm control of your behavior thoughts, emotions, } \\
\text { and feelings? }\end{array}$ & 2.66 & A good bit of the Time \\
\hline 6. Have you felt tense or high- strung? & 2.90 & A good bit of the Time \\
\hline 7. Have you felt calm and peaceful? & 2.42 & Some of the time \\
\hline 8. Have you felt emotionally stable? & 1.99 & Some of the time \\
\hline 9. Have you felt downhearted and blue? & 2.60 & A good bit of the Time \\
\hline 10. Were you able to relax without difficult? & 2.72 & A good bit of the Time \\
\hline 11. Have you felt restless, fidgety, or impatient? & 2.78 & A good bit of the time \\
\hline 12. Have you been moody, or brooded about things? & 3.90 & Most of the time \\
\hline 13. Have you felt cheerful, lighted-hearted? & 2.72 & A good bit of the Time \\
\hline 14. Have you been in low, or very low spirits? & 3.06 & A good bit of the time \\
\hline 15. Were you happy person? & 2.87 & A good bit of the Time \\
\hline 16. Did you feel you had nothing to look forward? & 2.50 & Some of the time \\
\hline 17. Have you felt so down in the dumps that nothing could cheer you up? & 2.09 & Some of the time \\
\hline 18. Have you been anxious or worried? & 2.03 & Some of the time \\
\hline Overall & $\mathbf{2 . 7 9}$ & A good bit of the time \\
\hline
\end{tabular}




\section{International Journal of Current Science Research and Review}

ISSN: 2581-8341

Volume 04 Issue 08 August 2021

DOI: 10.47191/ijesrr/V4-i8-12, Impact Factor: 5.825

IJCSRR@ 2021

www.ijesrr.org

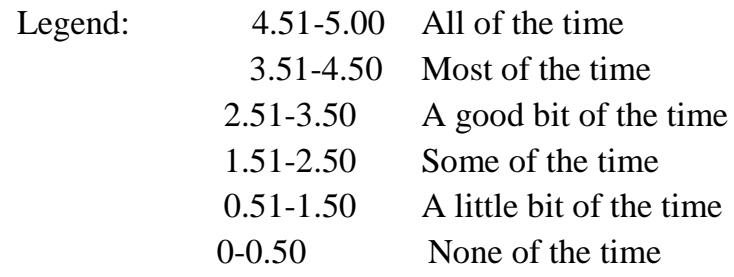

Detailed scrutiny of Table 3 reveals an overall mean of 2.72 which have a verbal interpretation of "A good bit of the time".

Table 3. Mean and Verbal Interpretation of the effects of the National Crisis on the Mental Health of the Students on Semester 3

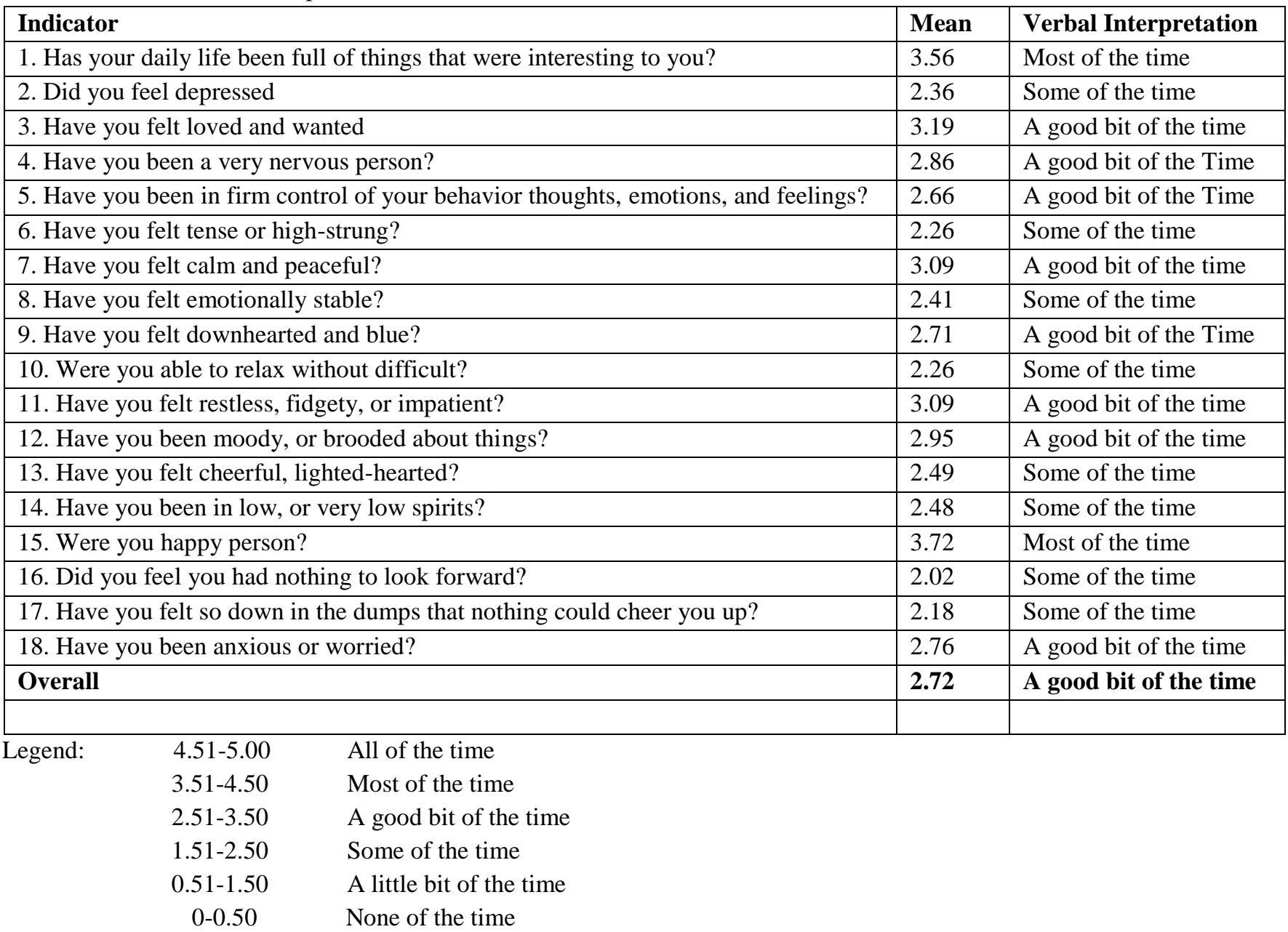

Predominantly, Table 4 reveals an overall mean of 2.69 which have a verbal interpretation of "A good bit of the time".

Table 4. Mean and Verbal Interpretation of the effects of the National Crisis on the Mental Health of the Students on Semester 4

\begin{tabular}{|l|l|l|}
\hline Indicator & Mean & Verbal Interpretation \\
\hline 1. Has your daily life been full of things that were interesting to you? & 2.94 & A good bit of the time \\
\hline 2. Did you feel depressed & 2.43 & Some of the time \\
\hline 3. Have you felt loved and wanted & 3.34 & A good bit of the time \\
\hline 4. Have you been a very nervous person? & 3.08 & A good bit of the Time \\
\hline
\end{tabular}




\section{International Journal of Current Science Research and Review}

ISSN: 2581-8341

Volume 04 Issue 08 August 2021

DOI: 10.47191/ijesrr/V4-i8-12, Impact Factor: 5.825

IJCSRR@ 2021

www.ijcsrr.org

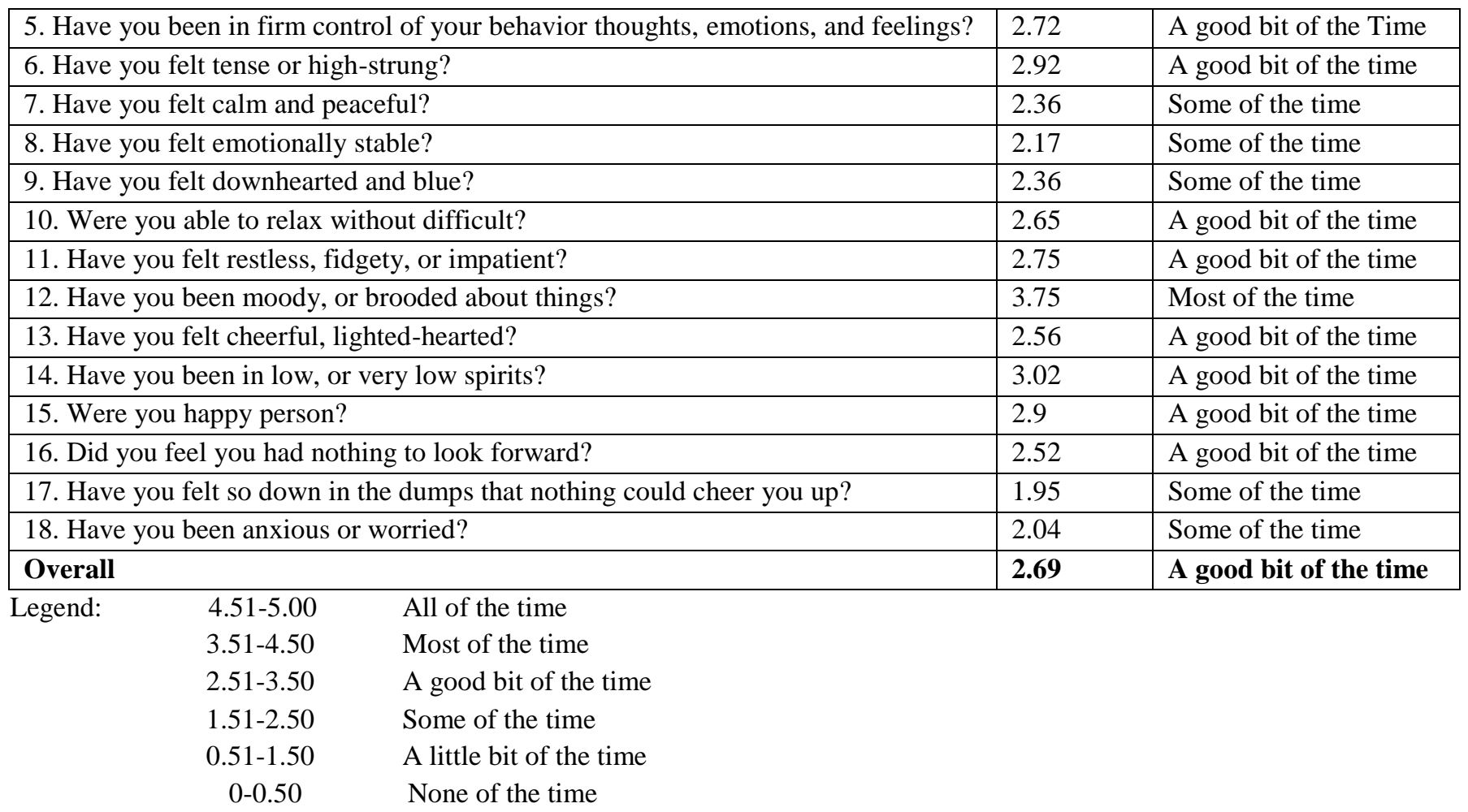

Detailed scrutiny of Table 5 reveals an overall mean of 2.59 which have a verbal interpretation of "A good bit of the time".

Table 5. Mean and Verbal Interpretation of the effects of the National Crisis on the Mental Health of the Students on Semester 5

\begin{tabular}{|l|l|l|}
\hline Indicator & Mean & Verbal Interpretation \\
\hline 1. Has your daily life been full of things that were interesting to you? & 3.69 & Most of the time \\
\hline 2. Did you feel depressed & 2.75 & A good bit of the time \\
\hline 3. Have you felt loved and wanted & 2.24 & Some of the time \\
\hline 4. Have you been a very nervous person? & 2.69 & A good bit of the Time \\
\hline 5. Have you been in firm control of your behavior thoughts, emotions, and feelings? & 2.35 & Some of the Time \\
\hline 6. Have you felt tense or high-strung? & 3.15 & A good bit of the time \\
\hline 7. Have you felt calm and peaceful? & 2.25 & Some of the time \\
\hline 8. Have you felt emotionally stable? & 2.89 & A good bit of the time \\
\hline 9. Have you felt downhearted and blue? & 3.13 & A good bit of the time \\
\hline 10. Were you able to relax without difficult? & 3.32 & A good bit of the time \\
\hline 11. Have you felt restless, fidgety, or impatient? & 2.35 & Some of the time \\
\hline 12. Have you been moody, or brooded about things? & 1.96 & Some of the time \\
\hline 13. Have you felt cheerful, lighted-hearted? & 1.99 & Some of the time \\
\hline 14. Have you been in low, or very low spirits? & 2.16 & Some of the time \\
\hline 15. Were you happy person? & 2.85 & A good bit of the time \\
\hline 16. Did you feel you had nothing to look forward? & 2.52 & A good bit of the time \\
\hline 17. Have you felt so down in the dumps that nothing could cheer you up? & 2.71 & A good bit of the Time \\
\hline 18. Have you been anxious or worried? & 1.71 & Some of the time \\
\hline Overall & $\mathbf{2 . 5 9}$ & A good bit of the time \\
\hline
\end{tabular}

Legend: $\quad 4.51-5.00 \quad$ All of the time




\section{International Journal of Current Science Research and Review}

ISSN: 2581-8341

Volume 04 Issue 08 August 2021

DOI: 10.47191/ijesrr/V4-i8-12, Impact Factor: 5.825

IJCSRR@ 2021

www.ijesrr.org

$\begin{array}{cl}3.51-4.50 & \text { Most of the time } \\ 2.51-3.50 & \text { A good bit of the time } \\ 1.51-2.50 & \text { Some of the time } \\ 0.51-1.50 & \text { A little bit of the time } \\ 0-0.50 & \text { None of the time }\end{array}$

Detailed scrutiny of Table 6 reveals an overall mean of 2.54 which have a verbal interpretation of "A good bit of the time".

Table 6. Mean and Verbal Interpretation of the effects of the National Crisis on the Mental Health of the Students on Semester 6

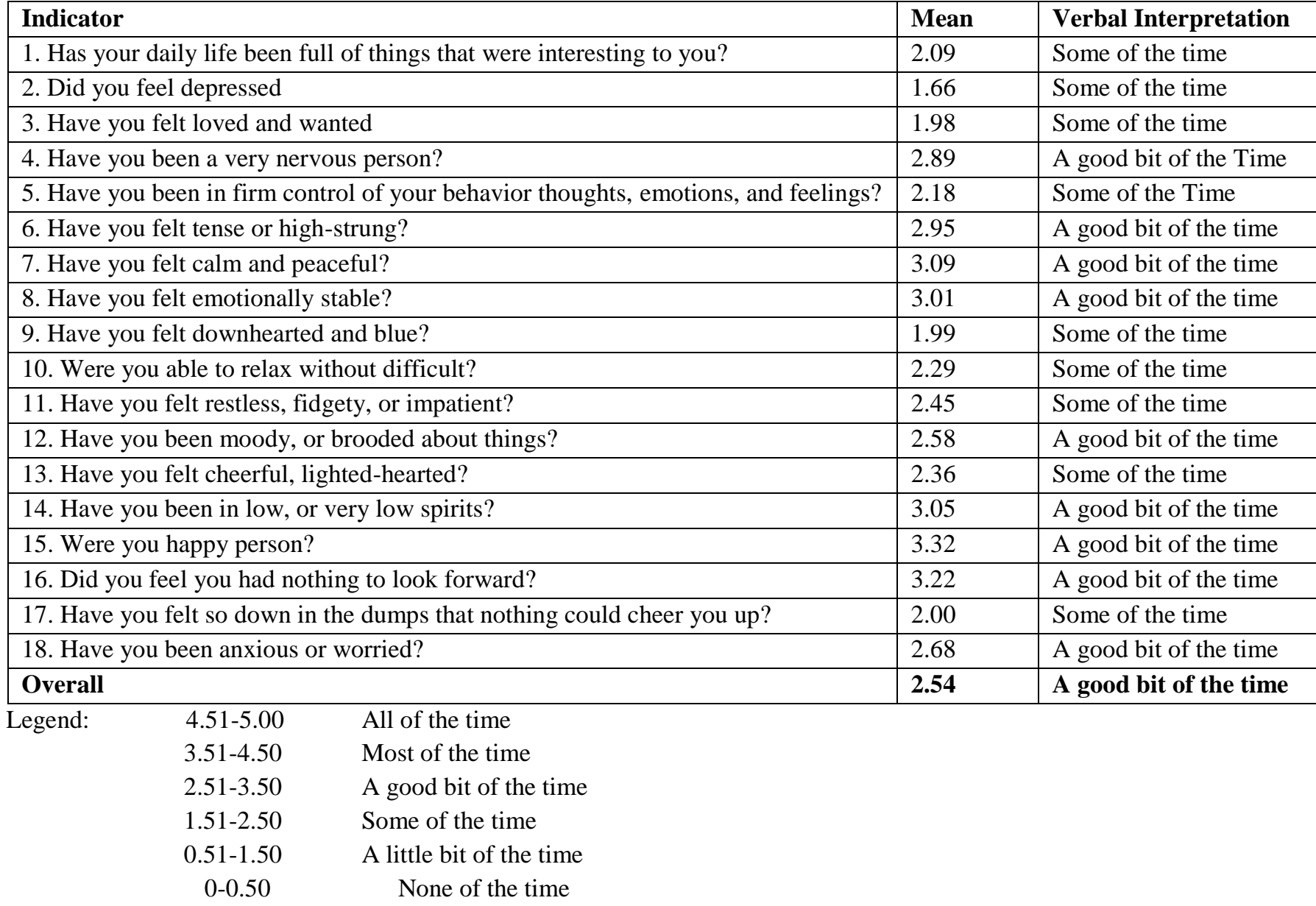

Cursory inspection of Table 7 reflecting the results of the overall mean of 2.72 disclosed that most of the indicator shows a verbal interpretation of "A good bit of the time".

Table 7. Mean and Verbal Interpretation of the effects of the National Crisis on the Mental Health of the Students on Semester 7

\begin{tabular}{|l|l|l|}
\hline Indicator & Mean & Verbal Interpretation \\
\hline 1. Has your daily life been full of things that were interesting to you? & 3.49 & A good bit of the time \\
\hline 2. Did you feel depressed & 3.26 & A good bit of the time \\
\hline 3. Have you felt loved and wanted & 2.89 & A good bit of the time \\
\hline 4. Have you been a very nervous person? & 3.43 & A good bit of the Time \\
\hline 5. Have you been in firm control of your behavior thoughts, emotions, and feelings? & 1.73 & Some of the Time \\
\hline
\end{tabular}




\section{International Journal of Current Science Research and Review}

ISSN: 2581-8341

Volume 04 Issue 08 August 2021

DOI: 10.47191/ijesrr/V4-i8-12, Impact Factor: 5.825

IJCSRR@ 2021

www.ijcsrr.org

\begin{tabular}{|l|l|l|}
\hline 6. Have you felt tense or high-strung? & 3.56 & Most of the time \\
\hline 7. Have you felt calm and peaceful? & 1.73 & Some of the time \\
\hline 8. Have you felt emotionally stable? & 1.99 & Some of the time \\
\hline 9. Have you felt downhearted and blue? & 3.43 & A good bit of the time \\
\hline 10. Were you able to relax without difficult? & 2.06 & Some of the time \\
\hline 11. Have you felt restless, fidgety, or impatient? & 3.09 & A good bit of the time \\
\hline 12. Have you been moody, or brooded about things? & 3.46 & A good bit of the time \\
\hline 13. Have you felt cheerful, lighted-hearted? & 1.53 & Some of the time \\
\hline 14. Have you been in low, or very low spirits? & 2.16 & Some of the time \\
\hline 15. Were you happy person? & 1.59 & Some of the time \\
\hline 16. Did you feel you had nothing to look forward? & 3.19 & A good bit of the time \\
\hline 17. Have you felt so down in the dumps that nothing could cheer you up? & 3.03 & A good bit of the time \\
\hline 18. Have you been anxious or worried? & 3.39 & A good bit of the time \\
\hline Overall & $\mathbf{2 . 7 2}$ & A good bit of the time \\
\hline
\end{tabular}

Legend:

All of the time

$3.51-4.50$

Most of the time

$2.51-3.50$

A good bit of the time

$1.51-2.50$

Some of the time

$0.51-1.50$

A little bit of the time

$0-0.50$

None of the time

Cursory inspection of Table 8 reflecting the results of the overall mean of 2.51 disclosed that most of the indicator shows a verbal interpretation of "A good bit of the time".

Table 8. Mean and Verbal Interpretation of the effects of the National Crisis on the Mental Health of the Students on Semester 8

\begin{tabular}{|l|l|l|}
\hline Indicator & Mean & Verbal Interpretation \\
\hline 1. Has your daily life been full of things that were interesting to you? & 2.33 & Some of the time \\
\hline 2. Did you feel depressed & 2.93 & A good bit of the time \\
\hline 3. Have you felt loved and wanted & 2.16 & Some of the time \\
\hline 4. Have you been a very nervous person? & 2.83 & A good bit of the Time \\
\hline 5. Have you been in firm control of your behavior thoughts, emotions, and feelings? & 2.09 & Some of the Time \\
\hline 6. Have you felt tense or high-strung? & 1.66 & Some of the time \\
\hline 7. Have you felt calm and peaceful? & 2.53 & A good bit of the time \\
\hline 8. Have you felt emotionally stable? & 1.89 & Some of the time \\
\hline 9. Have you felt downhearted and blue? & 2.23 & Some of the time \\
\hline 10. Were you able to relax without difficult? & 1.83 & Some of the time \\
\hline 11. Have you felt restless, fidgety, or impatient? & 3.16 & A good bit of the time \\
\hline 12. Have you been moody, or brooded about things? & 2.73 & A good bit of the time \\
\hline 13. Have you felt cheerful, lighted-hearted? & 3.16 & A good bit of the time \\
\hline 14. Have you been in low, or very low spirits? & 3.29 & A good bit of the time \\
\hline 15. Were you happy person? & 2.79 & A good bit of the time \\
\hline 16. Did you feel you had nothing to look forward? & 2.36 & Some of the time \\
\hline 17. Have you felt so down in the dumps that nothing could cheer you up? & 2.33 & Some of the time \\
\hline 18. Have you been anxious or worried? & 2.96 & A good bit of the time \\
\hline Overall & $\mathbf{2 . 5 1}$ & A good bit of the time \\
\hline
\end{tabular}

Legend: $\quad 4.51-5.00 \quad$ All of the time




\section{International Journal of Current Science Research and Review}

ISSN: 2581-8341

Volume 04 Issue 08 August 2021

DOI: 10.47191/ijesrr/V4-i8-12, Impact Factor: 5.825

IJCSRR@ 2021

www.ijcsrr.org

$\begin{array}{cc}3.51-4.50 & \text { Most of the time } \\ 2.51-3.50 & \text { A good bit of the time } \\ 1.51-2.50 & \text { Some of the time } \\ 0.51-1.50 & \text { A little bit of the time } \\ 0-0.50 & \text { None of the time }\end{array}$

Cursory inspection of Table 9 reveals that the summary on the effects of the National crisis on the mental health of the students disclosed the same verbal interpretation of "A good bit of the time" for all semester levels.

Table 9. Summary of the Mean and Verbal Interpretation of the effects of the National Crisis on the Mental Health of the Students at the Faculty of Nursing, University of Tripoli

\begin{tabular}{|l|l|l|}
\hline Semester & Mean & Verbal Interpretation \\
\hline 1 & 2.59 & A good bit of the time \\
\hline 2 & 2.79 & A good bit of the time \\
\hline 3 & 2.72 & A good bit of the time \\
\hline 4 & 2.69 & A good bit of the time \\
\hline 5 & 2.59 & A good bit of the time \\
\hline 6 & 2.54 & A good bit of the time \\
\hline 7 & 2.72 & A good bit of the time \\
\hline 8 & 2.51 & A good bit of the time \\
\hline
\end{tabular}

Detailed scrutiny of Table 10 reveals an overall mean of 64.99 which have a verbal interpretation of "Fair".

Table 10. Mean and Verbal Interpretation of the extent of the semester 1 student's level of academic performance as measured by their general weighted average

\begin{tabular}{|c|c|c|c|c|}
\hline \multicolumn{3}{|c|}{ Indicator } & Mean & Verbal Interpretation \\
\hline \multicolumn{3}{|c|}{ Anatomy } & 64.27 & Fair \\
\hline \multicolumn{3}{|l|}{ Arabic 1} & 58.37 & Fair \\
\hline \multicolumn{3}{|c|}{ Biostatistics } & 66.08 & Good \\
\hline \multicolumn{3}{|c|}{ English 1} & 60.05 & Fair \\
\hline \multicolumn{3}{|c|}{ Fundamentals of Nursing 1} & 71.46 & Good \\
\hline \multicolumn{3}{|c|}{ Introduction to Nursing } & 63.24 & Fair \\
\hline \multicolumn{3}{|l|}{ Overall } & 63.91 & Fair \\
\hline \multirow[t]{6}{*}{ Legend: } & $100-85$ & Excellent & & \\
\hline & $84.9-75$ & Very Good & & \\
\hline & $74.9-65$ & Good & & \\
\hline & $64.9-50$ & Fair & & \\
\hline & $49.9-35$ & Weak & & \\
\hline & $34.9-0$ & Very weak & & \\
\hline
\end{tabular}

Detailed scrutiny of Table 11 reveals an overall mean of 77.69 which have a verbal interpretation of "Very Good".

Table 11. Mean and Verbal Interpretation of the extent of the semester 2student's level of academic performance as measured by their general weighted average

\begin{tabular}{|c|c|c|}
\hline Indicator & "Mean & " Verbal Interpretation \\
\hline Arabic 2 & 76.00 & Good \\
\hline
\end{tabular}




\section{International Journal of Current Science Research and Review}

ISSN: 2581-8341

Volume 04 Issue 08 August 2021

DOI: 10.47191/ijesrr/V4-i8-12, Impact Factor: 5.825

IJCSRR@ 2021

Www.ijcsrr.org

\begin{tabular}{|c|c|c|c|c|}
\hline Compute & & & 51.93 & Fair \\
\hline English 2 & & & 50.00 & Fair \\
\hline Fundame & of Nursing & & 51.30 & Fair \\
\hline Physiolo & & & 77.64 & Very Good \\
\hline Sociolog & & & 81.60 & Very Good \\
\hline Overall & & & 64.74 & Fair \\
\hline Legend: & "100-85 & Excellent & & \\
\hline & $84.9-75$ & Very Good & & \\
\hline & $74.9-65$ & Good & & \\
\hline & $64.9-50$ & Fair & & \\
\hline & $49.9-35$ & Weak & & \\
\hline & $34.9-0$ & Very weak & & \\
\hline
\end{tabular}

Detailed scrutiny of Table 12 reveals an overall mean of 73.33 which have a verbal interpretation of "Good".

Table 12. Mean and Verbal Interpretation of the extent of the semester 3 student's level of academic performance as measured by their general weighted average

\begin{tabular}{|c|c|c|c|c|}
\hline \multicolumn{3}{|c|}{ Indicator } & Mean & Verbal Interpretation \\
\hline \multicolumn{3}{|c|}{ Biochemistry } & 74.59 & Good \\
\hline \multicolumn{3}{|c|}{ English 3} & 88.02 & Excellent \\
\hline \multicolumn{3}{|c|}{ Health Assessment } & 63.20 & Fair \\
\hline \multicolumn{3}{|c|}{ Health Education } & 79.88 & Very Good \\
\hline \multicolumn{3}{|c|}{ Pathophysiology } & 60.94 & Fair \\
\hline \multicolumn{3}{|c|}{ Overall } & 73.33 & Good \\
\hline \multirow[t]{6}{*}{ Legend: } & $2100-85$ & Excellent & & \\
\hline & $84.9-75$ & Very Good & & \\
\hline & $74.9-65$ & Good & & \\
\hline & $64.9-50$ & Fair & & \\
\hline & $49.9-35$ & Weak & & \\
\hline & $34.9-0$ & Very weak & & \\
\hline
\end{tabular}

Detailed scrutiny of Table 13 reveals an overall mean of 64.72 which have a verbal interpretation of "Fair".

Table 13. Mean and Verbal Interpretation of the extent of the semester 4 student's level of academic performance as measured by their general weighted average

\begin{tabular}{|c|c|c|c|c|}
\hline \multicolumn{3}{|c|}{ Indicator } & Mean & 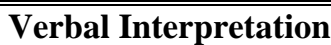 \\
\hline \multicolumn{3}{|c|}{ English 4} & 69.50 & Good \\
\hline \multicolumn{3}{|c|}{ General Psychology } & 68.81 & Good \\
\hline \multicolumn{3}{|c|}{ Microbiology } & 60.26 & Fair \\
\hline \multicolumn{3}{|c|}{ Pharmacology } & 60.29 & Fair \\
\hline \multicolumn{3}{|l|}{ Overall } & 64.72 & Fair \\
\hline \multirow[t]{5}{*}{ Legend: } & $100-85$ & Excellent & & \\
\hline & $84.9-75$ & Very Good & & \\
\hline & $74.9-65$ & Good & & \\
\hline & $64.9-50$ & Fair & & \\
\hline & $49.9-35$ & Weak & & \\
\hline
\end{tabular}




\section{International Journal of Current Science Research and Review}

ISSN: 2581-8341

Volume 04 Issue 08 August 2021

DOI: 10.47191/ijesrr/V4-i8-12, Impact Factor: 5.825

IJCSRR@ 2021

www.ijesrr.org

$$
\text { 34.9-0 Very weak }
$$

Detailed scrutiny of Table 14 reveals an overall mean of 71.08 which have a verbal interpretation of "Good".

Table 14. Mean and Verbal Interpretation of the extent of the semester 5student's level of academic performance as measured by their general weighted average

\begin{tabular}{|c|c|c|c|c|}
\hline \multicolumn{3}{|c|}{ Indicator } & Mean & Verbal Interpretation \\
\hline \multicolumn{3}{|l|}{ Ethics } & 70.18 & Good \\
\hline \multicolumn{3}{|c|}{ Mental Health } & 57.69 & Fair \\
\hline \multicolumn{3}{|l|}{ Nutrition } & 78.80 & Very Good \\
\hline \multicolumn{3}{|l|}{ NU 321} & 77.68 & Very Good \\
\hline \multicolumn{3}{|l|}{ Overall } & 71.08 & Good \\
\hline \multirow[t]{6}{*}{ Legend: } & $100-85$ & Excellent & & \\
\hline & $84.9-75$ & Very Good & & \\
\hline & $74.9-65$ & Good & & \\
\hline & $64.9-50$ & Fair & & \\
\hline & $49.9-35$ & Weak & & \\
\hline & $34.9-0$ & Very weak & & \\
\hline
\end{tabular}

Detailed scrutiny of Table 15 reveals an overall mean of 68.46 which have a verbal interpretation of "Good".

Table 15. Mean and Verbal Interpretation of the extent of the semester 6 student's level of academic performance as measured by their general weighted average

\begin{tabular}{|c|c|c|c|c|}
\hline \multicolumn{3}{|c|}{ Indicator } & "Mean & " Verbal Interpretation \\
\hline \multicolumn{3}{|c|}{ Community health Nursing } & 63.25 & Fair \\
\hline \multicolumn{3}{|c|}{ Research 1} & 65.86 & Good \\
\hline \multicolumn{3}{|l|}{ NU 324} & 76.27 & Very Good \\
\hline \multicolumn{3}{|l|}{ Overall } & 68.46 & Good \\
\hline \multirow[t]{6}{*}{ Legend: } & $100-85$ & Excellent & & \\
\hline & $84.9-75$ & Very Good & & \\
\hline & $74.9-65$ & Good & & \\
\hline & $64.9-50$ & Fair & & \\
\hline & $49.9-35$ & Weak & & \\
\hline & $34.9-0$ & Very weak & & \\
\hline
\end{tabular}

Detailed scrutiny of Table 16 reveals an overall mean of 71.08 which have a verbal interpretation of "Good".

Table 16. Mean and Verbal Interpretation of the extent of the semester 7 student's level of academic performance as measured by their general weighted average

\begin{tabular}{|c|c|c|c|}
\hline & Indicator & Mean & Verbal Interpretation \\
\hline NU 323 & & 72.50 & Good \\
\hline NU 423 & & 63.06 & Fair \\
\hline RLE 425 & & 77.70 & Very Good \\
\hline Overall & & 71.08 & Good \\
\hline end: & $\begin{array}{l}\text { Excellent } \\
\text { Very Good }\end{array}$ & & \\
\hline
\end{tabular}




\section{International Journal of Current Science Research and Review}

ISSN: 2581-8341

Volume 04 Issue 08 August 2021

DOI: 10.47191/ijesrr/V4-i8-12, Impact Factor: 5.825

IJCSRR@ 2021

www.ijcsrr.org

$\begin{array}{ll}74.9-65 & \text { Good } \\ 64.9-50 & \text { Fair } \\ 49.9-35 & \text { Weak } \\ 34.9-0 & \text { Very weak }\end{array}$

Detailed scrutiny of Table 17 reveals an overall mean of 75.46 which have a verbal interpretation of "Very Good".

Table 17. Mean and Verbal Interpretation of the extent of the semester 8 student's level of academic performance as measured by

\begin{tabular}{|c|c|c|c|c|}
\hline \multicolumn{3}{|c|}{ Indicator } & "Mean & Verbal Interpretation \\
\hline \multicolumn{3}{|c|}{ English 408} & 74.50 & Good \\
\hline \multicolumn{3}{|l|}{ INP 424} & 70.49 & Good \\
\hline \multicolumn{3}{|c|}{ MSN 424} & 80.57 & Very Good \\
\hline \multicolumn{3}{|c|}{ Nursing Reports } & 78.06 & Very Good \\
\hline \multicolumn{3}{|c|}{ Nursing Leadership \& Management } & 73.40 & Good \\
\hline \multicolumn{3}{|c|}{ RLE 426} & 75.72 & Very Good \\
\hline \multicolumn{3}{|l|}{ Overall } & 75.46 & Very Good \\
\hline \multirow[t]{6}{*}{ Legend: } & $100-85$ & Excellent & & \\
\hline & $84.9-75$ & Very Good & & \\
\hline & $74.9-65$ & Good & & \\
\hline & $64.9-50$ & Fair & & \\
\hline & $49.9-35$ & Weak & & \\
\hline & $34.9-0$ & Very weak & & \\
\hline
\end{tabular}

Cursory inspection of Table 18 reveals that the summary on the academic performance of the students disclosed that semester 8 have a verbal interpretation of "Very Good", semesters 3, 5, 6 and 7 as "Good" and semesters 1, 2 and 4 as "Fair".

Table 18. Mean and Verbal Interpretation of the summary of the extent of the student's level of academic performance as measured by their general weighted average

\begin{tabular}{|l|l|l|}
\hline Semester & Mean & Verbal Interpretation \\
\hline $\mathbf{1}$ & $\mathbf{6 3 . 9 1}$ & Fair \\
\hline $\mathbf{2}$ & $\mathbf{6 4 . 7 4}$ & Fair \\
\hline $\mathbf{3}$ & $\mathbf{7 3 . 3 3}$ & Good \\
\hline $\mathbf{4}$ & $\mathbf{6 4 . 7 2}$ & Fair \\
\hline $\mathbf{5}$ & $\mathbf{7 1 . 0 8}$ & Good \\
\hline $\mathbf{6}$ & $\mathbf{6 8 . 4 6}$ & Good \\
\hline $\mathbf{7}$ & $\mathbf{7 1 . 0 8}$ & Good \\
\hline $\mathbf{8}$ & $\mathbf{7 5 . 4 6}$ & Very Good \\
\hline Legend: & $100-85$ & Excellent \\
& $84.9-75$ & Very Good \\
& $74.9-65$ & Good \\
& $64.9-50$ & Fair \\
& $49.9-35$ & Weak \\
& $34.9-0$ & Very weak
\end{tabular}

Detailed analysis of table 19 reflecting the relationship between the two variables of the study which reveals a positive weak correlation. 


\section{International Journal of Current Science Research and Review}

ISSN: 2581-8341

Volume 04 Issue 08 August 2021

DOI: 10.47191/ijesrr/V4-i8-12, Impact Factor: 5.825

IJCSRR@ 2021

Www.ijcsrr.org

Table 19. Pearson Momentum Correlation between the Effects of the National Crisis on the mental health of the students and the student's level of academic performance

\begin{tabular}{|cl|l|}
\hline Variables & \\
\hline $\begin{array}{cl}\text { National Crisis effects on the } \\
\text { Mental health of students }\end{array}$ & Pearson Correlation & 0.26 \\
& Level of Sig & .13 \\
& $\mathrm{~N}$ & 247 \\
\hline $\begin{array}{cl}\text { Academic Performance } \\
\text { in Major Nursing Subjects }\end{array}$ & Pearson Correlation & 0.26 \\
$(\mathrm{Y})$ & $\mathrm{N}$ & .13 \\
& & 247 \\
\hline
\end{tabular}

There was a positive weak correlation between the two variables, $r=0.26 n=247, p=.13$

\section{DISCUSSION}

Based on the results from Table $1-8$, the University of Tripoli, Faculty of Nursing students from Semesters 1-8 effects of National Crisis on the mental health of the students falls with the same category of "A good bit of the time". Even at Table 9, it is surprising to note that the summary from all semester levels is the same. Indeed it can be said that the mental health of the students although not greatly affected, there's still some effects that could be seen and that it doesn't matter which semesters they are currently in.

In recent years, mental health of adolescents has taken considerable attention worldwide, because of a dramatic upward trend in suicide. More than twenty percent of adolescents in the U.S. have a mental health disorder, and one in five of them are affected by a mental health problem, which is estimated to account for a larger burden of disease than any other class of health conditions.

It is well known that mental health problems are related to deprivation, poverty, inequality and other social and economic determinants of health. Economic crises are therefore times of high risk to the mental well-being of the population and of the people affected and their families. ${ }^{3}$

Symptoms of a mental illness can be better or worse at times. This happens when people are doing their best to manage their illness, too. Experiencing worsening symptoms for a short period of time is a normal part of the recovery process. Sometimes we need outside help when symptoms become worse. Some people may also need urgent emergency help if they're at risk of hurting themselves or others. Fortunately, we can take steps to help control mental health crises and emergencies.

Most people affected by emergencies will experience distress (e.g. feelings of anxiety and sadness, hopelessness, difficulty sleeping, fatigue, irritability or anger and/or aches and pains). This is normal and will for most people improve over time. However, the prevalence of common mental disorders such as depression and anxiety is expected to more than double in a humanitarian crisis. ${ }^{5}$

The WHO stress that mental health is "more than just the absence of mental disorders or disabilities." Peak mental health is about not only avoiding active conditions but also looking after ongoing wellness and happiness. ${ }^{6}$

Multiple social, psychological, and biological factors determine the level of mental health of a person at any point of time. For example, violence and persistent socio-economic pressures are recognized risks to mental health. The clearest evidence is associated with sexual violence.

Poor mental health is also associated with rapid social change, stressful work conditions, gender discrimination, social exclusion, unhealthy lifestyle, physical ill-health and human rights violations. ${ }^{7}$

According to the World Health Organization (WHO), in armed conflict generally, an estimated $17 \%$ and $15 \%$ of the population will suffer from depression and post-traumatic stress disorder (PTSD), respectively. Several other major studies in post-conflict, low-income countries have reported even higher rates of mental health challenges among the population. Indeed, a 2010 study covering a region of Liberia revealed that some $45 \%$ of the population exhibited symptoms of PTSD nearly 20 years after the end of the conflict. Importantly, some studies have also shown a link between trauma exposure and views regarding 


\section{International Journal of Current Science Research and Review}

ISSN: 2581-8341

Volume 04 Issue 08 August 2021

DOI: 10.47191/ijcsrr/V4-i8-12, Impact Factor: 5.825

IJCSRR@ 2021

Www.ijcsrr.org

conflict resolution, with one study on northern Uganda finding that PTSD was correlated with support for violence as a means of conflict resolution. ${ }^{8}$

Ample research demonstrates the links between trauma exposure, including war-related trauma exposure, and the emergence of psychological distress. The 2015 Global Burden of Disease study found a positive association between conflict and depression and anxiety disorders. While most of those exposed to emergencies suffer some form of psychological distress, accumulated evidence shows that $15-20 \%$ of crisis-affected populations develop mild-to moderate mental disorders such as depression, anxiety, and post-traumatic stress. And, 3-4\% develop severe mental disorders, such as psychosis or debilitating depression and anxiety, which affect their ability to function and survive. ${ }^{9}$

A study of Sudanese refugees in northern Uganda found correlations between exposure to conflict, the prevalence of PTSD, and depressive and behavioral problems. It further found that the day-to-day hassles of life the children experienced were higher, relative to children in the same area who had not experienced conflict. PTSD is also associated with comorbidity of wide-ranging symptoms, from attempted suicide, to bronchial asthma, hypertension, peptic ulcer, among others. ${ }^{10}$

According to International Organization for Migration (IOM), Over the last ten years, the Libyan people have suffered tremendously from conflict, indiscriminate violence, but also from direct attacks on health care facilities, schools, water resources, and residential areas. Damage and destruction of essential facilities consequently led to collapse of functionality of society and to a major economic crisis. ${ }^{11}$

Another result from the study reveals that the academic performance of the students are not the same for semester 1-8. It is more difficult for the lower years like semester 1,2 and 4 to adapt as they revealed an overall interpretation of "Fair". And only students at the last semester was able to get the verbal interpretation of "Very Good". It is worthwhile to note that as the student progresses, the more likely for them to cope with their academic performance.

Adolescents showing strong mental health have good social skills with both adults and peers, and their enhanced social and emotional behaviors have a strong impact on academic achievement. Therefore, mental health problems in adolescents may have an important influence on academic achievement, which in turn have lifelong consequences for employment, income, and other outcomes.

Frequent feelings of mental health problems exhibit school difficulties, including poor academic achievement. Adolescents displaying strong mental health are likely to have better academic achievement, compared to adolescents displaying weak mental health. ${ }^{12}$

The study showed a weak positive correlation between 2 variables, the mental health of the students and their academic performance.

Student life can be stressful and for some students it may cause mental distress. Besides being a major public health challenge, mental distress can influence academic achievement. ${ }^{13}$

Mental health problems can affect many areas of students' lives, reducing their quality of life, academic achievement, physical health, and satisfaction with the college experience, and negatively impacting relationships with friends and family members. These issues can also have long-term consequences for students, affecting their future employment, earning potential, and overall health. ${ }^{14}$

Mental health problems can affect a student's energy level, concentration, dependability, mental ability, and optimism, hindering performance. Research suggests that depression is associated with lower grade point averages, and that co-occurring depression and anxiety can increase this association. Depression has also been linked to dropping out of school. ${ }^{15}$

The present meta-analysis aimed to determine the relationship between mental health and academic achievement in adolescents. This research, as expected, confirmed that there is a positive relationship between mental health and academic achievement. The research also indicated that mental health of adolescents is very important for schooling, in that it has a potential to influence academic achievement positively or negatively. Therefore, it is deemed crucial for adolescents to have a strong 


\section{International Journal of Current Science Research and Review}

ISSN: 2581-8341

Volume 04 Issue 08 August 2021

DOI: 10.47191/ijcsrr/V4-i8-12, Impact Factor: 5.825

IJCSRR@ 2021

WWw.ijcsrr.org

mental health to perform better academically in school, which in turn have lifelong consequences for employment, income, and other outcomes. ${ }^{16}$

According to the findings of this research, it can be concluded that the higher the mental health of the students, the better their educational performance. ${ }^{17}$

Our results showed that mental health was a stronger predictor of academic performance than other predictors and students whose mental health improved made better academic progress than students whose mental health did not improve or worsened. ${ }^{18}$

\section{CONCLUSIONS}

It can be said that the mental health of the students at the Faculty of Nursing was affected by the National Crisis on Libya "A good bit of the time". The results were not that high to affect their mental health status but it is still worthwhile to note that effects do exist and that mental health could be one area of concern to look into as WHO advocates a complete state of health.

It can be drawn that although the academic performance of some of the students are not that high, there was no weak or very weak in the results which proves that students are coping despite the crisis that they are experiencing.

Lastly, it can be said that the variables of the study correlates with each other, though it is just a weak relationship between variables, there is still a relationship that was established in the study and that we can still conclude that indeed the state of mental health of the student affects their academic performance.

\section{REFERENCES}

1. https://www. Aljazeera.com

2. https://www.intechopen.com/

3. https://www.euro.who.int/

4. https://www.heretohelp.bc.ca/

5. https://www.who.int/news-room/fact-sheets

6. https://www.medicalnewstoday.com/

7. https://www.who.int/news-room/fact-sheets/

8. https://www.sanaacenter.org/

9. https://www.Reliefweb.int

10. https://www.intechopen.com/

11. https://www.researchgate.net/publication

12. https://www.sprc.org/

13. https://www.sprc.org/colleges-universities/consequences

14. https://www.intechopen.com/

15. https://www.researchgate.net/publication

16. https://www.ncbi.nlm.nih.gov/pmc/

Cite this Article: Maria Cristina Arboleda-Tinay, RN, MAN, Evelyn Macasieb, RN, MSN, Joyce Juanita De Vera, RN, MAN, Jane Fabian, RN, MAN (2021). A Correlational Study on the Effect of National Crisis on the Mental Health of Students at the Faculty of Nursing, Tripoli Libya and their Academic Performance. International Journal of Current Science Research and Review, 4(8), 952-965 